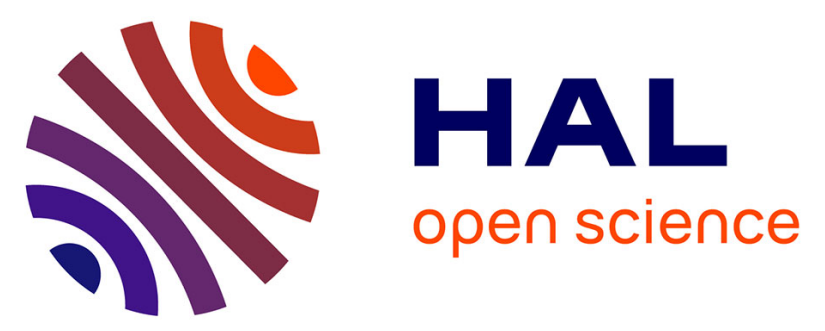

\title{
Heparin bridging therapy and bleeding events in octogenarian inpatients with atrial fibrillation starting anticoagulation: results of an ancillary study.
}

Dominique Bonnet-Zamponi, Marie-Claude Aumont, Emmanuelle Comets, Corinne Bruhat, Marie-Paul Chauveheid, Xavier Duval, Marie-Geneviève Huisse, Bertrand Diquet, Gilles Berrut, France Mentré, et al.

\section{To cite this version:}

Dominique Bonnet-Zamponi, Marie-Claude Aumont, Emmanuelle Comets, Corinne Bruhat, MariePaul Chauveheid, et al.. Heparin bridging therapy and bleeding events in octogenarian inpatients with atrial fibrillation starting anticoagulation: results of an ancillary study.. Journal of the American Geriatrics Society, 2011, 59 (11), pp.2174-8. 10.1111/j.1532-5415.2011.03649.x . inserm-00707902

\section{HAL Id: inserm-00707902 https://www.hal.inserm.fr/inserm-00707902}

Submitted on 1 Nov 2012

HAL is a multi-disciplinary open access archive for the deposit and dissemination of scientific research documents, whether they are published or not. The documents may come from teaching and research institutions in France or abroad, or from public or private research centers.
L'archive ouverte pluridisciplinaire HAL, est destinée au dépôt et à la diffusion de documents scientifiques de niveau recherche, publiés ou non, émanant des établissements d'enseignement et de recherche français ou étrangers, des laboratoires publics ou privés. 


\section{Heparin Bridging Therapy and bleeding events in octogenarians inpatients with atrial}

\section{fibrillation starting anticoagulation: Results of an ancillary study}

Bonnet-Zamponi D MD ${ }^{1}$, Aumont $\mathrm{MC} \mathrm{MD}{ }^{2,3}$, Comets $\mathrm{E} \mathrm{PhD}^{4,5}$, Bruhat $\mathrm{C} \mathrm{MD}^{6}$, Chauveheid MP MD ${ }^{7}$, Duval X MD ${ }^{3,8}$, Huisse MG MD ${ }^{9,3}$, Diquet B MD, $\mathrm{PhD}^{10}$, Berrut G MD, $\mathrm{PhD}^{11}$, Mentre F MD, $\mathrm{PhD}^{4,5}$, Delpierre $\mathrm{S} \mathrm{MD}{ }^{12}$, Legrain S MD ${ }^{3,12}$ ${ }^{1}$ AP-HP, Bichat-Claude Bernard Hospital, Department of Epidemiology, Biostatistics and Clinical Research, Paris, France; ${ }^{2}$ AP-HP, Bichat-Claude Bernard Hospital, Department of Cardiology, Paris, France; ${ }^{3}$ Univ Paris Diderot, Sorbonne Paris Cité, Department of Medicine, Paris, France ; ${ }^{4}$ National institute of Health and Medical Research (INSERM), UMR738, Paris, France; ${ }^{5}$ Univ Paris Diderot, Sorbonne Paris Cité, Department of Biostatistics, Paris, France; ${ }^{6}$ Angers Hospital, Department of Geriatrics, Angers, France ; ${ }^{7}$ AP-HP, Bichat-Claude Bernard Hospital, Department of Internal Medecine, Paris, France; ${ }^{8}$ AP-HP, Bichat-Claude Bernard Hospital, Centre of Clinical Investigation, Paris, France; ${ }^{9}$ AP-HP, Bichat-Claude Bernard Hospital, Department of Haematology, Paris , France; ${ }^{10}$ Univ Angers PRES L'UNAM, Department Biology of the infectious agents and the pharmacotoxicology, CHU Angers, France; ${ }^{11}$ Nantes Hospital, Department of Clinical Gerontology, Nantes, France; ${ }^{12}$ AP-HP, Bretonneau Hospital, Department of Geriatrics, Paris, France; 


\section{To the Editor:}

The prevalence of atrial fibrillation (AF) rises with advancing age reaching almost $10 \%$ in octogenarians ${ }^{1}$. Progress in medicine leads physicians to prescribe more Vitamin K antagonists (VKA) in octogenarians according to Evidence-Based Clinical Practice Guidelines $^{2,3,4}$. The guidelines are however unclear regarding the need for heparin bridging therapy (HBT) at the initiation of VKA in patient without indication for immediate cardioversion. Indeed, the American College of Cardiology (ACC), the American Heart Association (AHA) and the European Society of Cardiology (ESC) $)^{2,4}$ give no specific recommendation. The American College of Chest Physicians (ACCP) ${ }^{3}$ specifies that "stable patients with AF can be anticoagulated on an outpatient basis with VKAs alone" but adds that "For particularly worrisome patients, physicians may be more comfortable with a heparin/warfarin bridging regimen". Who are the "particularly worrisome" patients? Should HBT be prescribed in octogenarians with high risk for thromboembolism and low risk for bleeding, as assessed by scores?

This article reports the results of an ancillary study from a pharmacokinetic and pharmacodynamic study on fluindione in French octogenarian inpatients. This ancillary study aimed to characterize the rate of HBT use in octogenarians starting AF-related anticoagulation during an acute care stay and to describe the thrombotic and bleeding events occurring during this stay.

\section{METHOD:}

The multicenter, prospective PREPA study was conducted between September 2005 and September 2007 in 6 medical and 1 surgical (cardiac) acute-care units at 3 French universityaffiliated hospitals. The objective of the PREPA study was to model the pharmacokinetic and pharmacodynamic components of the response to fluindione in octogenarians inpatients starting fluindione (VKA-naive patients or after a 15-day wash-out) regardless of indication 
(AF,venous thrombo-embolism, valvular prosthesis). Consecutive patients were included and physicians managed drugs according to routine clinical practice, without any algorithm. Therefore this study reflects real life practice of HBT. For this ancillary study, analyses were restricted to patients who were newly prescribed VKA for AF. Exclusion criteria were: fluindione absolute contraindications, contraindicated comedication, inability to give informed consent, inclusion in another trial of therapeutic evaluation and expected length of stay $<3$ days. Patients were followed until their discharge from the study unit or during the subsequent 30 days after the inclusion. Causes for premature withdrawal from the study were death, consent withdrawal or prescription of Vitamin K and/or Prothrombin complex concentrates. All bleeding and embolic events occurring during the follow-up were collected. Bleeding was considered severe if it required stopping VKA and/or additional procedure and/or treatment. Scores for thrombo-embolism and bleeding risks, as described in the 2010 ESC guidelines ${ }^{4}$, were retrospectively assessed in patients with bleeding events.

\section{RESULTS}

Among the 132 included patients, 69 patients were newly prescribed VKA for AF. These patients were mostly females $(\mathrm{N}=44,64 \%)$ and had a mean age of $86 \pm 4$ years. $20(29 \%)$ patients were in post-operative care after cardiac surgery. The mean Charlson comorbidity index was $6.7 \pm 2.4$ and the patients had $8 \pm 3$ daily comedications at inclusion. Heparin or its derivatives were prescribed as a bridge therapy in $59(85.5 \%)$ of these patients. None had an indication of cardioversion. General attrition rate during PREPA study was high, with a short length of stay: $49.2 \%$ of the included patients remained in the study at D7, $56.2 \%$ in the subgroup of AF-patients new to VKA. No thrombotic event occurred in the 69 VKA-naive AF patients during the study follow-up, whether they received HBT or not. Eight of these patients (11.6\%) experienced bleeding (cf table1). All of them were considered to be at high risk of thrombo-embolism according to the CHA(2)DS(2)-VASc ${ }^{4}$ score and at low-risk of bleeding 
according to the HAS-BLED bleeding risk score ${ }^{4}$ Bleeding was severe in 5 patients $(7.2 \%)$, with one related death. These severe bleedings occurred in the first 4 days and were always associated to HBT: in 3 cases, an heparin over-dosage was observed despite a correct heparin initial dose, in 1 case the INR was above the target range simultaneously to intercurrent infectious disease and the last occurred in a patient with a triple antithrombotic therapy and a very unstable health status. No thrombopenia was observed in the patients with a bleeding event.

\section{DISCUSSION}

This study showed a high rate $(85.5 \%)$ of HBT use in octogenarians with AF starting VKA in acute-care units. The rate of bleeding events occurring in these patients during the first week of the fluindione initiation was very high (11.6\%), especially the rate of severe bleeding $(7.2 \%)$.

Inception cohorts ${ }^{5,6}$ have established that bleeding risk is increased in AF octogenarians (especially in the first 90 days). The incidence of bleedings ranges from 1.9 to $13.1 / 100$ person-years, but this estimate is subject to selection and methodological biases ${ }^{7,8}$. These cohorts included outpatients or mixed populations, the VKA (warfarin) was managed by anticoagulation clinics and the rate of heparin bridging therapy was not specified. The rate of bleeding in our small cohort is particularly worrying. It may be explained by the studied population (very old patients with unstable clinical status) with VKA (fluindione) managed by hospital clinicians without algorithm. The high rate of HBT may also have contributed to these bleedings, at least in 3 patients with an anti-Xa activity above the upper therapeutic range. However, heparin was not contra indicated in our population, according to the scores assessing risks of bleedings and of thrombotic events (cf table 1).It is surprising that the HASBLED score, which has the best predictive value of several bleeding risk stratification schemas $^{9}$, concluded wrongly to a low risk for bleeding (maximum risk of 1.88 bleeds per 100 
patient years) in our patients with bleeding. The retrospective assessment of the score may have underestimated some items, notably alcohol use and labile INR. Above all, this score, which is based on almost 4,000 out and inpatients in the EuroHeart Survey on AF (mean Age $66+/-13$ years) followed during one year for major bleeding, probably does not adapt well to octogenarian inpatients starting anticoagulation.

Our study has important limits due to its ancillary feature. First, the number and characteristics of the eligible non included patients were not recorded, precluding assessment of the sample representativity. Second, the high attrition rate could have induced an underestimation of bleeding and thrombotic events, especially those occurring after discharge. Nevertheless, our study underlines (i) the inappropriateness of the HAS-BLED score to predict individual risk of bleeding in octogenarian inpatients so that "known risk factors for increased risk of bleeding should be taken into account on an individual basis when starting anticoagulation"11 and (ii) the need for future well-designed studies to provide relevant evidence to make recommendations for HBT administration in octogenarians inpatients with AF. 


\section{ACKNOWLEDGMENTS}

Conflict of Interest: All authors declare that (1) no authors have support for the submitted work; (2) no author have relationships with companies that might have an interest in the submitted work in the previous 3 years; (3) their spouses, partners, or children have no financial relationships that may be relevant to the submitted work; and (4) no author have non-financial interests that may be relevant to the submitted work.

\section{Conflict of Interest Disclosures:}

\begin{tabular}{|c|c|c|c|c|c|c|c|c|c|c|c|c|c|c|c|c|c|c|}
\hline \multirow[t]{2}{*}{$\begin{array}{l}\text { Elements of } \\
\text { Financial/Personal } \\
\text { Conflicts }\end{array}$} & \multicolumn{2}{|c|}{$\begin{array}{l}\text { Author } 1 \\
\text { D.Bonnet- } \\
\text { Zamponi }\end{array}$} & \multicolumn{2}{|c|}{$\begin{array}{l}\text { Author } 2 \\
\text { MC } \\
\text { Aumont }\end{array}$} & \multicolumn{2}{|c|}{$\begin{array}{l}\text { Author } 3 \\
\text { E Comets }\end{array}$} & \multicolumn{2}{|c|}{$\begin{array}{l}\text { Author } 4 \\
\text { C Bruhat }\end{array}$} & \multicolumn{2}{|c|}{$\begin{array}{l}\text { Author } 5 \\
\text { MP } \\
\text { Chauveheid }\end{array}$} & \multicolumn{2}{|c|}{$\begin{array}{l}\text { Author } 6 \\
\text { X Duval }\end{array}$} & \multicolumn{2}{|c|}{$\begin{array}{l}\text { Author } 7 \\
\text { MG } \\
\text { Huisse }\end{array}$} & \multicolumn{2}{|c|}{$\begin{array}{l}\text { Author } 8 \\
\text { B Diquet }\end{array}$} & \multicolumn{2}{|c|}{$\begin{array}{l}\text { Author } 9 \\
\text { G Berrut }\end{array}$} \\
\hline & Yes & No & Yes & No & Yes & No & Yes & No & Yes & No & Yes & No & Yes & No & Yes & No & Yes & No \\
\hline $\begin{array}{l}\text { Employment or } \\
\text { Affiliation }\end{array}$ & & $\mathrm{X}$ & & $\mathrm{X}$ & & $\mathrm{X}$ & & $\mathrm{X}$ & & $\mathrm{X}$ & & $\mathrm{X}$ & & $\mathrm{X}$ & & $\mathrm{X}$ & & $\mathrm{X}$ \\
\hline & & & & & & & & & & & & & & & & & & \\
\hline Grants/Funds & & $\mathrm{X}$ & & $\mathrm{X}$ & & $\mathrm{X}$ & & $\mathrm{X}$ & & $\mathrm{X}$ & & $\mathrm{X}$ & & $\mathrm{X}$ & & $\mathrm{X}$ & & $\mathrm{X}$ \\
\hline Honoraria & & $X$ & & $X$ & & $X$ & & $X$ & & $X$ & & $X$ & & $\mathrm{X}$ & & $X$ & & $X$ \\
\hline & & & & & & & & & & & & & & & & & & \\
\hline Speaker Forum & & $X$ & & $\mathrm{X}$ & & $\mathrm{X}$ & & $\mathrm{X}$ & & $\mathrm{X}$ & & $\mathrm{X}$ & & $\mathrm{X}$ & & $X$ & & $X$ \\
\hline Consultant & & $\mathrm{X}$ & & $\mathrm{X}$ & & $X$ & & $\mathrm{X}$ & & $X$ & & $X$ & & $\mathrm{X}$ & & $\mathrm{X}$ & & $\mathrm{X}$ \\
\hline Stocks & & $\mathrm{X}$ & & $\mathrm{X}$ & & $X$ & & $\mathrm{X}$ & & $\mathrm{X}$ & & $\mathrm{X}$ & & $\mathrm{X}$ & & $\mathrm{X}$ & & $\mathrm{X}$ \\
\hline Royalties & & $\mathrm{X}$ & & $\mathrm{X}$ & & $X$ & & $\mathrm{X}$ & & $\mathrm{X}$ & & $\mathrm{X}$ & & $\mathrm{X}$ & & $\mathrm{X}$ & & $\mathrm{X}$ \\
\hline Expert Testimony & & $\mathrm{X}$ & & $\mathrm{X}$ & & $\mathrm{X}$ & & $\mathrm{X}$ & & $\mathrm{X}$ & & $\mathrm{X}$ & & $\mathrm{X}$ & & $\mathrm{X}$ & & $\mathrm{X}$ \\
\hline & & & & & & & & & & & & & & & & & & \\
\hline
\end{tabular}




\begin{tabular}{|c|c|c|c|c|c|c|c|c|c|c|c|c|c|c|c|c|c|c|}
\hline Board Member & & $\mathrm{X}$ & & $\mathrm{X}$ & & $\mathrm{X}$ & & $\mathrm{X}$ & & $\mathrm{X}$ & & $\mathrm{X}$ & & $\mathrm{X}$ & & $\mathrm{X}$ & & $\mathrm{X}$ \\
\hline Patents & & $\mathrm{X}$ & & $\mathrm{X}$ & & $\mathrm{X}$ & & $\mathrm{X}$ & & $\mathrm{X}$ & & $\mathrm{X}$ & & $\mathrm{X}$ & & $\mathrm{X}$ & & $\mathrm{X}$ \\
\hline & & & & & & & & & & & & & & & & & & \\
\hline Personal Relationship & & $\mathrm{X}$ & & $\mathrm{X}$ & & $\mathrm{X}$ & & $\mathrm{X}$ & & $\mathrm{X}$ & & $\mathrm{X}$ & & $\mathrm{X}$ & & $\mathrm{X}$ & & $\mathrm{X}$ \\
\hline $\begin{array}{l}\text { Elements of } \\
\text { Financial/Personal } \\
\text { Conflicts }\end{array}$ & $\begin{array}{l}\text { Autho } \\
\text { F Me }\end{array}$ & & $\begin{array}{l}\text { Auth } \\
\text { S } \\
\text { Delp }\end{array}$ & $\begin{array}{l}11 \\
\text { rre }\end{array}$ & $\begin{array}{l}\text { Auth } \\
\text { S Le }\end{array}$ & & & & & & & & & & & & & \\
\hline & Yes & No & Yes & No & Yes & No & Yes & No & Yes & No & Yes & No & Yes & No & Yes & No & Yes & No \\
\hline $\begin{array}{l}\text { Employment or } \\
\text { Affiliation }\end{array}$ & & $\mathrm{X}$ & & $\mathrm{X}$ & & $\mathrm{X}$ & & & & & & & & & & & & \\
\hline & & & & & & & & & & & & & & & & & & \\
\hline Grants/Funds & & $\mathrm{X}$ & & $\mathrm{X}$ & & $\mathrm{X}$ & & & & & & & & & & & & \\
\hline & & & & & & & & & & & & & & & & & & \\
\hline Honoraria & & $\mathrm{X}$ & & $\mathrm{X}$ & & $\mathrm{X}$ & & & & & & & & & & & & \\
\hline & & & & & & & & & & & & & & & & & & \\
\hline Speaker Forum & & $\mathrm{X}$ & & $\mathrm{X}$ & & $\mathrm{X}$ & & & & & & & & & & & & \\
\hline & & & & & & & & & & & & & & & & & & \\
\hline Consultant & & $\mathrm{X}$ & & $\mathrm{X}$ & & $\mathrm{X}$ & & & & & & & & & & & & \\
\hline & & & & & & & & & & & & & & & & & & \\
\hline Stocks & & $\mathrm{X}$ & & $\mathrm{X}$ & & $\mathrm{X}$ & & & & & & & & & & & & \\
\hline & & & & & & & & & & & & & & & & & & \\
\hline Royalties & & $\mathrm{X}$ & & $\mathrm{X}$ & & $\mathrm{X}$ & & & & & & & & & & & & \\
\hline & & & & & & & & & & & & & & & & & & \\
\hline Expert Testimony & & $\mathrm{X}$ & & $\mathrm{X}$ & & $\mathrm{X}$ & & & & & & & & & & & & \\
\hline & & & & & & & & & & & & & & & & & & \\
\hline Board Member & & $\mathrm{X}$ & & $\mathrm{X}$ & & $\mathrm{X}$ & & & & & & & & & & & & \\
\hline & & & & & & & & & & & & & & & & & & \\
\hline Patents & & $X$ & & $X$ & & $X$ & & & & & & & & & & & & \\
\hline
\end{tabular}




\begin{tabular}{|l|l|l|l|l|l|l|l|l|l|l|l|l|l|l|l|l|l|l|}
\hline & & & & & & & & & & & & & & & & & & \\
\hline Personal Relationship & & $\mathrm{X}$ & & $\mathrm{X}$ & & $\mathrm{X}$ & & & & & & & & & & & & \\
\hline
\end{tabular}

\section{Author Contributions:}

Bonnet-Zamponi D : DBZ 'Aumont MC :MCA, Comets Eः EC, Bruhat C :CB Chauveheid MP :MPC Duval X: XD, Huisse MG :MGH, Diquet B:BD, Berrut G :GB Delpierre S SD, Mentre F: FM, Legrain S :SL

Concept and Design: SL, FM, BD, GB, SD, EC

Acquisition of subject and data: MCA, EC, CB, MPC, XD, MGH, SD, SL, DBZ

Analysis and interpretation of data: DBZ, EC, SL, FM, BD, MCA

Preparation of manuscript: DBZ

Critical review and approval: DBZ, MCA, EC, CB, MPC, XD, MGH, BD, GB, SD, FM, SL

Sponsor's Role: None 


\section{REFERENCES}

1- Go AS, Hylek EM, Phillips KA, et al. Prevalence of diagnosed atrial fibrillation in adults: national implications for rhythm management and stroke prevention: the AnTicoagulation and Risk Factors in Atrial Fibrillation (ATRIA) Study. JAMA. 2001 May 9;285(18):2370-5.

2- Zipes DP, Camm AJ, Borggrefe M, et al; American College of Cardiology/American Heart Association Task Force; European Society of Cardiology Committee for Practice Guidelines; European Heart Rhythm Association; Heart Rhythm Society. ACC/AHA/ESC 2006

Guidelines for Management of Patients With Ventricular Arrhythmias and the Prevention of Sudden Cardiac Death: a report of the American College of Cardiology/American Heart Association Task Force and the European Society of Cardiology Committee for Practice Guidelines (writing committee to develop Guidelines for Management of Patients With Ventricular Arrhythmias and the Prevention of Sudden Cardiac Death): developed in collaboration with the European Heart Rhythm Association and the Heart Rhythm Society. Circulation. 2006 Sep 5;114(10):e385-484. Epub 2006 Aug 25.

3- Singer DE, Albers GW, Dalen JE, et al. Antithrombotic therapy in atrial fibrillation: American College of Chest Physicians Evidence-Based Clinical Practice Guidelines (8th Edition). Chest. 2008;133(6 Suppl):546S-592S.

4- European Heart Rhythm Association; European Association for Cardio-Thoracic Surgery, Camm AJ, Kirchhof P, Lip GY, Schotten U, et al.Guidelines for the management of atrial fibrillation: the Task Force for the Management of Atrial Fibrillation of the European Society of Cardiology (ESC). Eur Heart J. 2010 Oct;31(19):2369-429. Epub 2010 Aug 29. 
5- Hylek EM, Evans-Molina C, Shea C, et al. Major hemorrhage and tolerability of warfarin in the first year of therapy among elderly patients with atrial fibrillation.Circulation. 2007 May 29;115(21):2689-96. Epub 2007 May 21.

6-Poli D, Antonucci E, Grifoni E, et al. Bleeding risk during oral anticoagulation in atrial fibrillation patients older than 80 years.J Am Coll Cardiol. 2009 Sep 8;54(11):999-1002.

7- Ono A, Kawamura I, Fujita T. Letter regarding article by Hylek et al, "Major hemorrhage and tolerability of warfarin in the first year of therapy among elderly patients with atrial fibrillation". Circulation. 2007 Nov 13;116(20):e538.

8- Cowan A, Hylek EM. Bleeding risk on warfarin among elderly patients with atrial fibrillation J Am Coll Cardiol. 2010 Mar 2;55(9):932; author reply 932-3.

9- Lip GY, Frison L, Halperin JL, et al.Comparative validation of a novel risk score for predicting bleeding risk in anticoagulated patients with atrial fibrillation: the HAS-BLED (Hypertension, Abnormal Renal/Liver Function, Stroke, Bleeding History or Predisposition, Labile INR, Elderly, Drugs/Alcohol Concomitantly) score.J Am Coll Cardiol. 2011 Jan 11;57(2):173-80. Epub 2010 Nov 24.

10- Pisters R, Lane DA, Nieuwlaat R, et al. A novel user-friendly score (HAS-BLED) to assess 1-year risk of major bleeding in patients with atrial fibrillation: the Euro Heart Survey.Chest. 2010 Nov;138(5):1093-100. Epub 2010 Mar 18.

11- Palareti G, Cosmi B. Bleeding with anticoagulation therapy - who is at risk, and how best to identify such patients. Thromb Haemost. 2009 Aug;102(2):268-78. 




\section{Table 1 : Bleeding events during the PREPA study (severe bleedings in grey)}

\begin{tabular}{|c|c|c|c|c|c|c|c|c|c|c|c|c|}
\hline $\begin{array}{l}\text { Type of AF } \\
\text { and } \\
\text { AF-related } \\
\text { symptoms } \\
\text { (EHRA score) }^{4}\end{array}$ & Age & Sex & Surgery & $\begin{array}{l}\mathrm{CHA}_{2} \mathrm{DS}_{2} \mathrm{VASc} \text { score } \\
\text { and risk stratification* }\end{array}$ & $\begin{array}{l}\text { HAS-BLED } \\
\text { bleeding risk } \\
\text { scoreand risk } \\
\text { stratification }^{\dagger}\end{array}$ & $\begin{array}{l}\text { Type of } \\
\text { bleeding } \\
\text { event }\end{array}$ & $\begin{array}{l}\text { a) VKA stop } \\
\text { b) additionnal } \\
\text { treatment } \\
\text { c) additional } \\
\text { investigations }\end{array}$ & $\begin{array}{l}\text { Date of } \\
\text { bleeding } \\
\end{array}$ & INR $>3^{\S}$ & HBT & $\begin{array}{l}\text { AntiXa } \\
\text { or PTT } \\
>\text { therapeutic } \\
\text { target }^{\S}\end{array}$ & Comments \\
\hline $\begin{array}{l}\text { First diagnosed AF } \\
\text { Dyspnea } \\
\text { (EHRA 4) }\end{array}$ & 83 & M & No & $4=$ High risk & $2=$ low risk & $\begin{array}{l}\text { Abdominal } \\
\text { wall } \\
\text { haematoma } \\
(9 X 6 \mathrm{~cm}) \\
\text { with anemia } \\
(7.8 \mathrm{~g} / \mathrm{dl})) \\
\end{array}$ & $\begin{array}{l}\text { a) Yes } \\
\text { b) Blood } \\
\text { transfusion } \\
+ \text { Vitamin K } \\
\text { c) Abdominal } \\
\text { echography }\end{array}$ & D4 & $\begin{array}{l}\text { Yes } \\
3,37\end{array}$ & $\begin{array}{l}\text { Yes } \\
\text { LMWH }\end{array}$ & No & $\begin{array}{l}\text { Infectious event with prescription of } \\
\text { Telithromycin respectively at D0 and } \\
\text { D1 } \\
\text { Fluindione dose was decreased from } 15 \\
\text { to } 10 \mathrm{mg} \text { at D2 }\end{array}$ \\
\hline $\begin{array}{l}\text { First diagnosed AF } \\
\text { Dyspnea } \\
\text { (EHRA 4) }\end{array}$ & 88 & $\mathrm{M}$ & No & $4=$ High risk & $2=$ low risk & $\begin{array}{l}\text { Hemorrhagic } \\
\text { shock on } \\
\text { digestive } \\
\text { hemorrhage } \\
\text { with anemia } \\
(5 \mathrm{~g} / \mathrm{dl})\end{array}$ & $\begin{array}{l}\text { a) Yes } \\
\text { b) Blood } \\
\text { transfusion } \\
+ \text { Gelofusine } \\
\text { c) UGE }\end{array}$ & D2 & $\begin{array}{l}\text { No } \\
1.45\end{array}$ & $\begin{array}{l}\text { Yes } \\
\text { LMWH }\end{array}$ & No & $\begin{array}{l}\text { Severe infectious disease before } \\
\text { fluindione start with increased CRP } \\
\text { (68), low serum albumin (28g/l) and } \\
\text { prescription of Lévofloxacine (D-10 to } \\
\text { D0) and amoxicillin clavulanic acid ( } \\
\text { D-8 to D0). } \\
\text { Aspirin was stopped at D-1 }\end{array}$ \\
\hline $\begin{array}{l}\text { Permanent AF } \\
\text { No symptom } \\
\text { (EHRA 1) }\end{array}$ & 85 & $\mathrm{M}$ & No & $4=$ High risk & $2=$ low risk & $\begin{array}{l}\text { Psoas } \\
\text { Haematoma }\end{array}$ & $\begin{array}{l}\text { a) Yes } \\
\text { b) No } \\
\text { c) TDM }\end{array}$ & D4 & $\begin{array}{l}\text { No } \\
1.45\end{array}$ & $\begin{array}{l}\text { Yes } \\
\text { UFH }\end{array}$ & Yes & \multirow{2}{*}{$\begin{array}{l}\text { Initial dose of HBT adjusted to } \\
\text { clearance } \\
\text { and weight ( moderate renal failure at } \\
\text { admission) } \\
\text { No acute failure during the stay }\end{array}$} \\
\hline $\begin{array}{l}\text { First diagnosed AF } \\
\text { Dyspnea } \\
\text { (EHRA 4) }\end{array}$ & 88 & $\mathrm{~F}$ & No & $4=$ High risk & $2=$ low risk & $\begin{array}{l}\text { Ankle } \\
\text { haematoma }\end{array}$ & $\begin{array}{l}\text { a) Yes } \\
\text { b) Yes } \\
\text { c) No }\end{array}$ & D3 & $\begin{array}{l}\text { No } \\
1.44\end{array}$ & $\begin{array}{l}\text { Yes } \\
\text { Calcium } \\
\text { heparin }\end{array}$ & Yes & \\
\hline $\begin{array}{l}\text { First diagnosed AF } \\
\text { No symptom } \\
\text { (EHRA 1) }\end{array}$ & 85 & $\mathrm{~F}$ & No & 4 = High risk & $1=$ low risk & $\begin{array}{l}\text { Hemorrhagic } \\
\text { shock with } \\
\text { death }\end{array}$ & $\begin{array}{l}\text { a) Yes } \\
\text { b) Yes } \\
\text { c) No }\end{array}$ & D2 & $\begin{array}{l}\text { No } \\
1.39\end{array}$ & $\begin{array}{l}\text { Yes } \\
\text { LMWH }\end{array}$ & Yes & $\begin{array}{l}\text { Documented acute renal failure at D3 } \\
\text { (no renal failure at admission) }\end{array}$ \\
\hline $\begin{array}{l}\text { First diagnosed AF } \\
\text { Dyspnea } \\
\text { (EHRA 3) }\end{array}$ & 92 & $\mathrm{~F}$ & No & $4=$ High risk & $2=$ low risk & Epistaxis & $\begin{array}{l}\text { a) No } \\
\text { b) No } \\
\text { c) No }\end{array}$ & D6 & $\begin{array}{l}\text { No } \\
2.68\end{array}$ & $\begin{array}{l}\text { Yes } \\
\text { LMWH }\end{array}$ & No & $\begin{array}{l}\text { Documented acute renal failure at D4 } \\
\text { (moderate renal failure at admission) }\end{array}$ \\
\hline $\begin{array}{l}\text { Persistent AF } \\
\text { No symptom } \\
\text { (EHRA 1) }\end{array}$ & 82 & $\mathrm{~F}$ & $\begin{array}{l}\text { Yes: } \\
\text { Aortic valve } \\
\text { remplacement }\end{array}$ & $5=$ High risk & $2=$ low risk & $\begin{array}{l}\text { Rectum } \\
\text { haemorrhage }\end{array}$ & $\begin{array}{l}\text { a) No } \\
\text { b) No } \\
\text { c) No }\end{array}$ & D8 & $\begin{array}{l}\text { No } \\
2.61\end{array}$ & No & $\mathrm{NA}$ & \\
\hline $\begin{array}{l}\text { Paroxysmal AF } \\
>48 \mathrm{~h} \\
\text { feeling of faintness } \\
\text { (EHRA 4) } \\
\end{array}$ & 83 & $\mathrm{~F}$ & No & $3=$ High risk & $1=$ low risk & $\begin{array}{l}\text { Rectum } \\
\text { haemorrhage }\end{array}$ & $\begin{array}{l}\text { a) No } \\
\text { b) No } \\
\text { c) No }\end{array}$ & D3 & $\begin{array}{l}\text { No } \\
2.82\end{array}$ & No & NA & \\
\hline
\end{tabular}

*items of CHA2DS2VASc score : 'major' risk factors weigthed two points are "Previous stroke/ transient ischaemic attack.or systemic embolism" and "Age > 75 years",

Clinically relevant non-major' risk factors weighted one point are : "Heart failure or moderate to severe Left Ventricular systolic dysfunction (e.g. < 40\%)" and

"Hypertension" and" Diabetes mellitus" and "Female sex" and "Age 65-74 years" and "Vascular disease"

items of HAS-BLED score :Hypertension defined as systolic blood pressure $>160 \mathrm{mmHg}$ (1 point), presence of chronic dialysis or renal transplantation or serum creatinine

$\geq 200 \mu \mathrm{mol} / \mathrm{L}$ (1 point), Abnormal liver function defined by chronic hepatic disease (e.g. cirrhosis) or biochemical evidence of significant hepatic derangement (e.g. bilirubin 
$.2 \mathrm{x}$ upper limit of normal, in association with aspartate aminotransferase/alanine aminotransferase/alkaline phosphatase .3 x upper limit normal, etc. (one point), stroke (one point), previous bleeding history and/or predisposition to bleeding, e.g. bleeding diathesis, anaemia,(one point) labile INRs (one point- this item was systematically weighted zero in our study), age>65 years (one point), concomitant use of drug (antithrombotic agents, non-steroidal anti-inflammatory drugs etc) (one point) or alcohol (one point )

${ }^{\dagger} \mathrm{D} 0=$ Day of fluindione initiation

${ }^{\S}$ the day of the bleeding event

$\mathrm{AF}=$ Atrial Fibrillation ; $\mathrm{CRP}=\mathrm{C}-$ Reactive Protein $;$ EHRA =European Heart Rhythm Association ; HBT $=$ Heparin Bridging Therapy ; HTA $=$ Hypertension ; LMWH=Low-

Molecule-Weight Heparin ; NA = Non adapted item ; PTT= Partial Thromboplastin Time ; TDM= Tomodensitometry ; UGE= Upper Gastrointestinal Endoscopy ; UFH=

Unfractionned Heparin ; VKA= Vitamin K antagonist 